\title{
Evolution of Park Planning in City of Vancouver
}

\author{
Stephen Appiah Takyi \\ PhD Candidate, NRES, \\ University of Northern British Columbia.
}

\begin{abstract}
Historically, urban parks have been at the top of the list of communtity demands and, as so, are fundamental in master plans, urban policies, and capital improvement programs. In this article, Stephen Takyi discusses the evolution of park planning in Vancouver, and notes how the implementation of recreational facilities and physical structures in parks may be at odds with their ecological function.
\end{abstract}

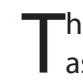
he study of park history serves as an important basis for assessing how rapid growth of cities affects the availability, management, and use of parks over time. The data used for this study was collected from a variety of documentary sources including Parks Board records, old newspapers and archival records. The development of parks in the City of Vancouver has been approached from a multi-stakeholder perspective since the 19th century. There has been an increase in the number of physical structures and area of hard landscaping on the parks. This is as a result of the continuous increase in the provision of more recreational facilities. The presence of more recreational facilities on the parks has helped in promoting social activities but has limited the ecological functions of the parks. This shows a conflict between the achievement of social and environment goals in park planning.

\section{Introduction}

Despite the importance of park history in the study, planning and management of urban parks, there is a major research gap within the Canadian context. This study addresses the knowledge gap of park literature from the historical perspective. The overall objective of this study is to analyze the Post-World War II historical patterns and trends in the development of parks in the City of Vancouver. The evolutionary history of urban parks according to Toledo \& dos Santos (2012) has helped in the assessment of the roles and purposes of park spaces over time. The study of historical trends of urban parks serves as the basis for assessing how rapid growth of cities affects the availability, management and use of these parks over time. The definition and description of parks changes with time based on the use, characteristics, ownership, management, or purpose of their development.

Williams (2002) argues that urban parks were once defined as pleasure grounds set aside for public recreation and the promotion of health and enjoyment. Williams (2002) further noted that these public green spaces provided cities with tangible benefits that go beyond serving as an outlet for recreation, physical activity, and relaxation. 19th century park visionaries such as Frederick Law Olmsted argued that parks were not amenities but rather necessities providing recreation, inspiration, and essential respite from the city's blare and bustle (Sherer, 2003).

Historically, the urgent need to improve living conditions in cities led to development of urban parks to help preserve the natural environment. According to Hinds (1979), the desire to improve the city's living conditions resulted in the development of the naturalistic park. Therefore, an attempt by city authorities to maintain some characteristics of the country in the city led to the development of parks. The changes in design, funding, ownership, management and use of urban parks over time have implications for their contemporary management. As population shifted to the suburbs after World War II, the vision of parks for all faded because many cities lacked the resources to create new parks (Sherer, 2003). This implies that the availability of land and financial resources has a lot of implications for the development and maintenance of parks.

Cranz (1982) presented the historical overview of urban parks in the United States where the parks were categorized into the pleasure ground (1850-1900), the reform park (1900-1930), the recreational facility (1930-1965), and the open space system (1965+). These categorizations were based on uses, characteristics, design elements, and architecture, which gave historical differences in the description of parks. The need for city parks as pleasure grounds according to Sherer (2003) arose in the second half of the 19th century where American cities built grand city parks to improve their residents' quality of life. According to Cranz (1982), American parks were conceived as pleasure grounds meant to bring the pieces of the country with its fresh air, meadow, lakes and sunshine to the cities.

The reformation of the park system between 1900 and 1930 saw the programming of park activities into physical, social, aesthetic and civic activities. Parks were used for a variety of activities as well as landscape beauty thus moving beyond 
pleasure (Cranz, 1982). According to Cranz (1982) park administrators in the 1930s abandoned their idealistic efforts to use parks as a mechanism for social reform. The use of available urban spaces for social activities during the recreation era (1930-1965) limited the availability of open spaces.

Byrne \& Sipe (2010), on the other hand classified parks based on size, deemed function, their geographic location and the types of facilities present within the parks and the degree of naturalness of the parks. According to Byrne \& Sipe (2010), parks can further be identified by factors such as:

- the activities that occur within the park and the types of people who use the park;

- the agency responsible for managing the park and the land use history of the area;

- the history and condition of the park; and

- the landscaping, embellishments and the philosophy behind the development of the park.

These factors helped in analyzing the historical trends of the park system in the City of Vancouver based on the purpose of establishing the parks, activities undertaken in the parks and agencies responsible for financing and managing these parks.

\section{Research Questions}

- What are the Post-World War II historical pattems and trends in park development in the City of Vancouver?

- What are the implications of these patterns and trends for Contemporary Park planning and management?

- How have culture and social diversity inf uenced the use and management of parks in the City of Vancouver?

\section{The Case Study}

Flyvbjerg (2006) describes a case study as a detailed examination of a single example of a class of phenomena. Field studies are so costly and complex that, they can be done only in one or few geographic areas hence the need to select case studies for in-depth studies (Sudman, 1976). The City of Vancouver is currently noted for its ambitious plan to become the world's most sustainable city through the formulation of policies to protect its natural environment including its green spaces.

According to Horak \& Young (2012), the City of Vancouver has consistently been ranked among the growth leaders within Canadian urban system since the deep recessions in the 1980s.

The city's urban parks give a broader view on the study of parks due to their social, environmental and economic characteristics and benefits. The City of Vancouver has a population of 603,502 with a population density of 5,249.1 people per square kilometres (Statistics Canada, 2012). The City of Vancouver is one of the most diverse cities in the world thus making it a single case study with diverse socio-economic background. The diverse population of the city coupled with its continuous population growth makes it an important case study for assessing how the demographic changes in the city affects the availability, management and use of parks over time. A map showing the parks in the City of Vancouver has been presented in Figure 1.

The use of documentary sources of information is likely to be relevant to every case study topic except studies of preliterate societies (Yin, 2010). The analysis of historical trends of parks development in the City of Vancouver relied on secondary sources of data. Hakim (1982) defines secondary data analysis as any further analysis of an existing dataset which presents interpretations, conclusions or knowledge additional to, or different from, those produced in the original report of an inquiry. Table 1 shows a summary of the research method and process used for the study.

The use of secondary sources of data is less costly and less time consuming than the collection of primary data. This is because the secondary sources of data have already been summarized and analyzed mostly from past primary data which are mostly in the form of archival records, journals and government documents. However, collecting secondary data from one source could be highly biased since it may only represent one perspective. The historical data was collected from internet sources, library sources, Vancouver Archival Services, the Vancouver Parks Board, news coverage and other documentary information from the City of Vancouver departments and boards relevant to the study.

\section{Historical Overview: Pre-World War II}

The historical background of parks in the City of Vancouver is a major contributory factor to the high value city residents place on the provision and management of parks. The City of Vancouver has a history of a multi-stakeholder approach to the development of parks. Garvin \& Berens (1997) grouped the trends in the development of open spaces into two conven-

Figure 1: Map Showing the Parks in the City of Vancouver.

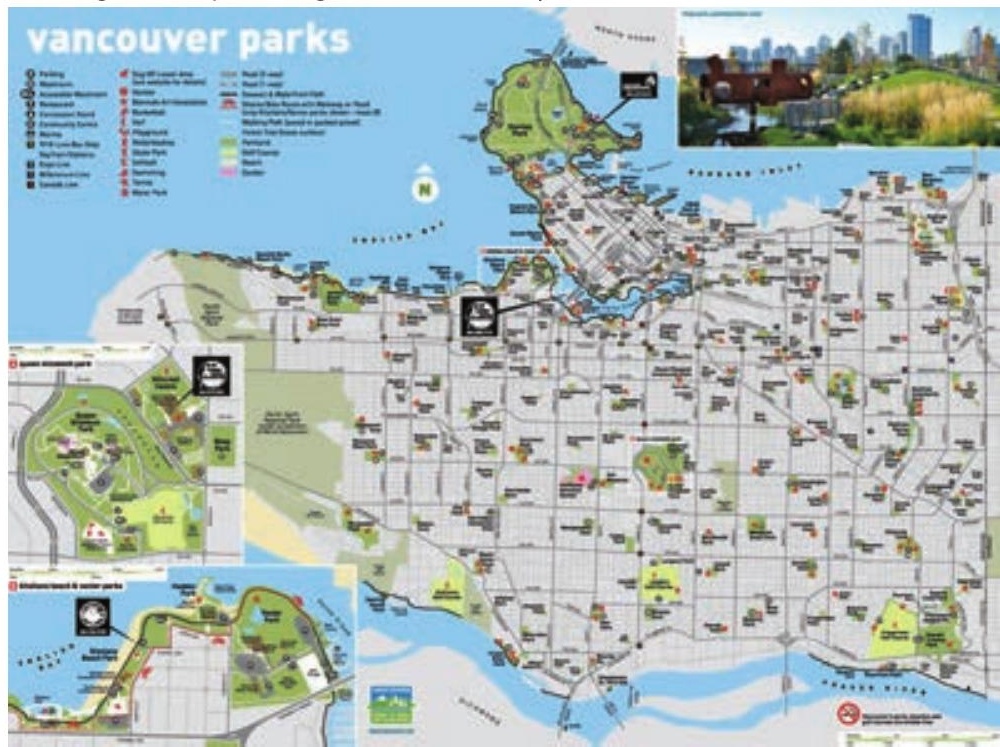


Table 1: Research methods and techniques.

\begin{tabular}{|c|c|}
\hline $\begin{array}{l}\text { Emerging Issues From } \\
\text { Literature Review }\end{array}$ & $\begin{array}{l}\text { - Design, funding, ownership, management and use of parks changes over time. } \\
\text { - The definition and description of parks changes with time based on the use, ownership, } \\
\text { management or purpose of their development. } \\
\text { - Cranz (1982) has presented the historical overview of urban parks in the United States. } \\
\text { Park history can be assessed based on uses, characteristics, design elements and } \\
\text { architecture which gave historical differences in the description of parks. }\end{array}$ \\
\hline What is Missing & $\begin{array}{l}\text { - Literature on how the design, ownership, characteristics and management of parks in } \\
\text { Canada has changed overtime. }\end{array}$ \\
\hline What is Researchable & - $\quad$ Post-World War II historical patterns and trends in park development in Vancouver. \\
\hline Research Hypothesis & $\begin{array}{l}\text { - Historical patterns and trends of urban park development in the City of Vancouver have } \\
\text { informed current urban park development. }\end{array}$ \\
\hline Specific Questions & $\begin{array}{l}\text { - What were the main purposes of establishing parks in Vancouver? } \\
\text { - Who were some of the stakeholders involved in the development and management of the } \\
\text { parks? } \\
\text { - What were some of the challenges facing the development and management of parks? } \\
\text { - What are the historical trends in the ownership and use of parks? } \\
\text { - What are the historical trends in the characteristics of parks? }\end{array}$ \\
\hline Dependent Variables & $\begin{array}{ll} & \text { Historical patterns and trends }(1945-1965) \\
\text { - } & \text { Historical patterns and trends }(1965+)\end{array}$ \\
\hline Independent Variables & $\begin{array}{ll} & \text { The purpose of developing the parks } \\
\text { - } & \text { Actors involved in parks development } \\
\text { - } & \text { Park Ownership } \\
\text { - } & \text { Characteristics of Parks } \\
\end{array}$ \\
\hline Type of Methods & $\begin{array}{ll}\text { - } & \text { Content Analysis of Archival Records } \\
\text { - } & \text { Old Newspapers } \\
\text { - } & \text { Document Analysis of Parks Board Records }\end{array}$ \\
\hline Justification of Methods & $\begin{array}{l}\text { - Historical data are used in answering explanatory questions of how and why? } \\
\text { - Historical analysis can only be done based on already existing data sources. } \\
\text { - Vancouver Archival Services has the most comprehensive records of park history. } \\
\text { - Vancouver Sun being one of the oldest newspapers in the city has records of past } \\
\text { publication accessible to the public and researchers. }\end{array}$ \\
\hline Specific Methods & $\begin{array}{l}\text { - City of Vancouver Archival Records } \\
\text { Checked descriptions of records that are part of the Board of Parks and Recreation } \\
\text { Checked records pertinent to the themes of the study } \\
\text { Vancouver Parks Board Documents } \\
\text { Identified all parks and group them into year groups } \\
\text { Calculated total number and park acreage for each year group } \\
\text { Identified historical trends and patterns for each year group }\end{array}$ \\
\hline Data Sources & $\begin{array}{ll} & \text { City of Vancouver Archival Records } \\
\text { - } & \text { Vancouver Parks Board Records }\end{array}$ \\
\hline $\begin{array}{l}\text { Expected Data to Be Collected } \\
\text { (Dependent Variables) }\end{array}$ & $\begin{array}{l}\text { Post-World War II historical trends and patterns: } \\
\text { - The purpose of developing the parks } \\
\text { - } \quad \text { Actors involved in parks development } \\
\text { - Park Ownership } \\
\text { - } \quad \text { Characteristics of Parks }\end{array}$ \\
\hline Data Analysis & $\begin{array}{l}\text { - Data analyzed using Cranz (1982) year groups as a guide but with emphasis on post-World } \\
\text { - War II trends (1945-1965 and } 1965+\text {. } \\
\text { Developed a spread sheet for each year group helping the calculate the total number of } \\
\text { parks and park Acreage } \\
\text { - Calculation of the Population Park ration and the population density to access the trends } \\
\text { and patterns } \\
\text { - Analysis of the historical trends and patterns for each theme under each year group } \\
\text { - Use of tables to summarise research findings }\end{array}$ \\
\hline
\end{tabular}

tional models and one new model. The conventional models are the public sector approach and a hybrid of both the public sector and private sector approach. The newer model comprises of the market-oriented civic model. This model relies on long term partnership between the public and private sectors for park development through taxes, private donations and revenue producing park functions (Garvin \& Berens, 1997).

The historical trends of park development in the City of Vancouver clearly indicate the application of the elements of all these three models in the 19th century. However, there is a major shift to a more governmental and private sector approach in the 21 st century, with the City of Vancouver Parks Board and developers being the main actors. The development of urban parks in the City of Vancouver started in 1888 when a 950 acre military reserve was converted into a park (City of Vancouver Archives, 1997). The location of Stanley Park, according to the City of Vancouver Archives (1997) was also originally the home of the Burrard, Musqueam and Squamish First Nations people.

The transformation of human settlement into a park in the City of Vancouver indicated a major shift from man's role as a conqueror of nature as discussed by McHarg (1971). Historically, the survival and wealth of man depended mostly on their ability to clear the natural vegetation for agricultural purposes and other economic activities such as mining and hunting. However, in the case of Stanley Park, human settlement had to make way for the creation of the park for nature conservation. The creation of Stanley Park therefore, contradicted the historical role of man as a conqueror of the environment for 
survival. Figure 2 shows a picture of the human settlement on present day Stanley Park in 1860.

Stanley Park was not purposely designed like the famous Central Park in New York which was designed by Frederick Law Olmstead and Calvert Vaux. Stanley Park evolved as the home of First Nation groups to its present status as the largest park in the City of Vancouver. The park like many others in the 19th Century was developed to help connect the city's residents to nature and also promote active recreation. This role does not generally deviate from the traditional reasons for developing parks. McHarg (1971) argued that the problem of man and nature is not one of providing a decorative background for the human play but its necessity for sustaining nature as a source of life. The Pre-World War II development of parks involved a variety of stakeholders such as the Park Wardens, Park Committee Members, Canadian Pacific Railway (CPR), city residents and private individuals. Table 2 provides a summary of the major actors involved in park development during the Pre-World War II era.

Overall, there are 220 parks in the City of Vancouver with $30.91 \%$ of these parks created before World War II. A total of 2,528 acres of land were developed into parks before World War II. This constitutes $64.75 \%$ of the total park area in the City of Vancouver. The total area of park developed before World War II was greater than the total park area developed after World War II. The number of parks created in the City of Vancouver before World War II was, however, less than the

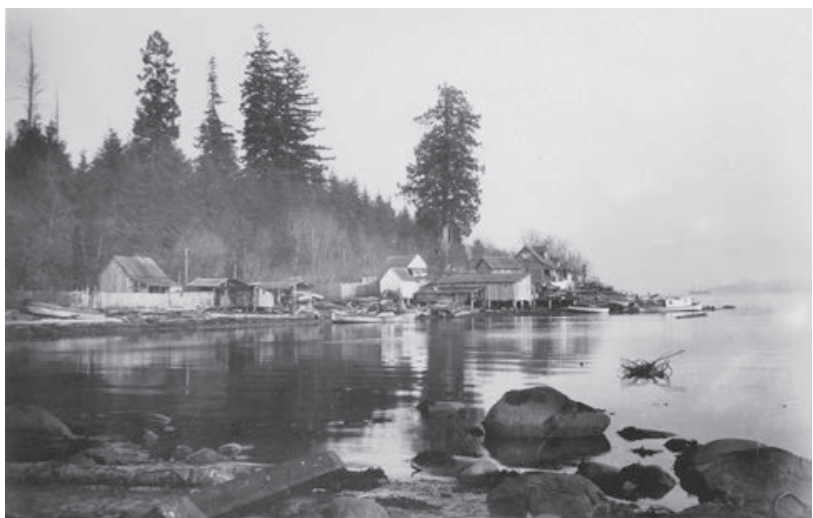

Figure 2: The area turned into Stanley Park as in 1860. (source: City of Vancouver)

number of parks created after World War II. This implies that the demographic expansion of the City of Vancouver adversely affected the total area of parks developed but there was no adverse effect on the number of parks.

There is therefore, the need for park researchers and stakeholders to distinguish between the number of parks available in a city and the total park area of a city. The creation of larger parks helps to increase the ecological benefits of parks to the city as it increases the total land area available for green spaces. The debate on size versus number of parks as a measure of park development is yet to dominate in park literature and policy debates. The measure of the availability

Table 2: Actors involved in the development of parks in Vancouver, Pre-World War II.

(Source: Vancouver Park Board, 2014)

\begin{tabular}{|c|c|c|}
\hline Stakeholder & Role & Specific Examples \\
\hline $\begin{array}{l}\text { Park Warden and } \\
\text { Park Committee }\end{array}$ & $\begin{array}{l}\text { - Park management } \\
\text { - Purchase of land for park } \\
\text { development } \\
\text { - Naming of parks }\end{array}$ & $\begin{array}{l}\text { - Park Board approved nearby residents to plant market } \\
\text { gardens in undeveloped area of Connaught Park in } 1921 \\
\text { - Park Board approved plans for community center on } \\
\text { Hastings Community Park in } 1934 \\
\text { - Renaming of English Bay Park to Alexandra Park in } 1911\end{array}$ \\
\hline Private Individuals & $\begin{array}{l}\text { - Donation of private properties } \\
\text { - Sale of land for park } \\
\text { development } \\
\text { - Funding }\end{array}$ & $\begin{array}{l}\text { - Land for Garden Park purchased from P.W. Charleson in } \\
1912 \\
\text { - William Harold Malkin gave the land for Malkin Park to } \\
\text { Vancouver Park Board. } \\
\text { - William Malkin donated money for Malkin Bowl in } \\
\text { Stanley Park } \\
\text { - Land for Tatlow Park was purchased from T.E Calland in } \\
\text { 1907. }\end{array}$ \\
\hline $\begin{array}{l}\text { Canadian Pacific } \\
\text { Railway }\end{array}$ & $\begin{array}{l}\text { Sale and donation of land for } \\
\text { park development }\end{array}$ & $\begin{array}{l}\text { - Langara Park was first owned by CPR and developed as a } \\
\text { golf course in } 1926 . \\
\text { - CPR donated Angus Park to the city of Vancouver. }\end{array}$ \\
\hline Other Private Entities & Funding & $\begin{array}{l}\text { - Pacific Lawn Bowling Club built indoor facility on } \\
\text { Grimmett Park in } 1937\end{array}$ \\
\hline Communal Support & Funding & $\begin{array}{l}\text { - Private Citizens raised money to purchase the beach } \\
\text { front land of Kitsilano Beach Park from CPR } \\
\text { - Community groups in Hastings Area raised funds for the } \\
\text { construction of a Fieldhouse-like structure on Hastings } \\
\text { Community Park in } 1934\end{array}$ \\
\hline City Council & Administration & - Appointment of Park Wardens and Park Committees \\
\hline Provincial Government & Funding and donation of land & $\begin{array}{l}\text { - Carnarvon Park was secured by tax sales from the BC } \\
\text { Government } \\
\text { - Provincial Government donated the land for McBride } \\
\text { Park to the Park Board in } 1911 \text {. }\end{array}$ \\
\hline
\end{tabular}


of parks in a city could either be based on the total number of available parks or the total park area. It is however more feasible and effective if both indicators are used, especially if the main aim of creating the park is to promote economic, social and ecological benefits.

There is a general theoretical argument about the effect of city expansion on the availability of land for park development. In the case of the City of Vancouver, the demographic and economic expansion of the city has limited the ability for the city to create large parks. This explains why all the large parks in the city such as Stanley Park, Queen Elizabeth Park and Hastings Park were all created before World War II. It also explains why the total area of parks created in the Pre-World War II is greater than the Post-World War II era. Figure 3 shows the pictorial representation of Queen Elizabeth Park which was created in 1902.

Historically, parks were developed to preserve the natural environments of cities by helping to maintain some of the environmental elements of the country in the city. The availability of land also influences the size of the park to be developed. The findings of the study revealed that the creation of all the large parks in the City of Vancouver before World War II was basically a result of the less pressure on land resources compared to the increasing pressure on land in the Post-World War II era.

\section{Park Development from 1945 to 1965}

The economy of the City of Vancouver expanded after World War Il due to the development of the war and ship building industry. The selling of large quantities of wheat to China in 1961 contributed immensely to the expansion of commercial activi-

Figure 3: Queen Elizabeth Park, created in 1902.

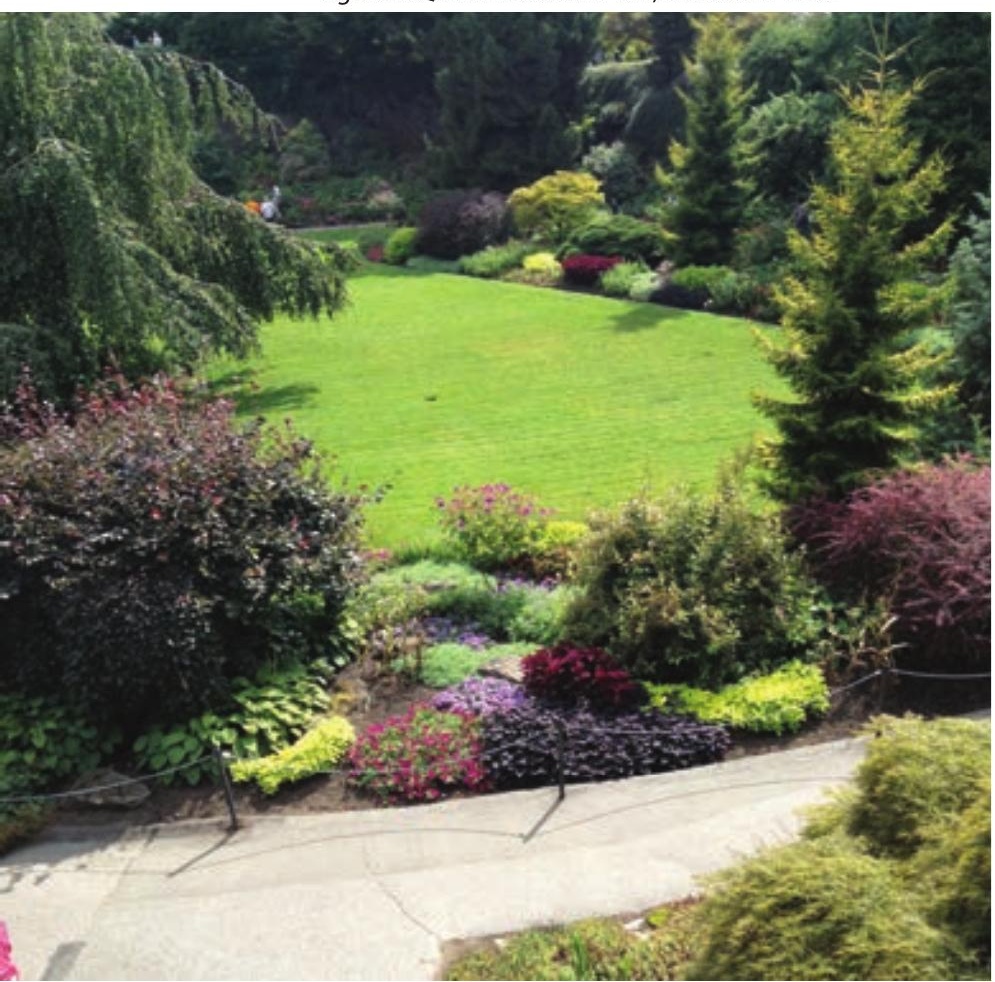

ties in the city. According to the Canadian Encyclopedia (2014), the easing of immigration restrictions and the attractiveness of a booming economy drew new immigrants after World War II thus making the City of Vancouver more cosmopolitan. The socio-economic expansion of the city had implications for the development of parks. This necessitated the need to study the historical trends of park development and its implications to contemporary park management.

\section{Purpose of Park Development (1945-1965)}

The purpose of establishing parks during this era was in response to the increasing and diversifying park needs of the Post World War II emanating from the baby boom and industrial revolution. Parks were created to provide recreational facilities for children and pleasure ground for social activities such as picnics for the working class. The Post-World War II purpose of providing parks shifted from preserving the natural environments of the city to a more social oriented purpose. The social -oriented goals were achieved through the provision of more recreational facilities.

McBride Park which was used for the cultivation of vegetables during World War I was upgraded with various recreational facilities including field houses, playgrounds, soccer fields, tennis courts and washrooms (Vancouver Parks Board, 2014). Most of the newly developed parks were provided with recreational facilities while some of the existing parks were also upgraded with recreational facilities (Figure 4).

Generally, the number of physical structures and area of concrete surfaces on the parks increased due to an increase in the construction of pavements and recreational activities. Parks such as Connaught Park which was established in 1921, got the construction of its community center approved in 1948 (Vancouver Parks Board, 2014). Parks developed during this period also served specific suburban neighborhoods thus leading to the creation of more neighborhood parks. This implies that the Post World War II suburban development due to the over reliance on auto mobiles also affected the nature, type and pur-

Figure 4: McBride Park. (source: Vancouver Parks Board, 2014)

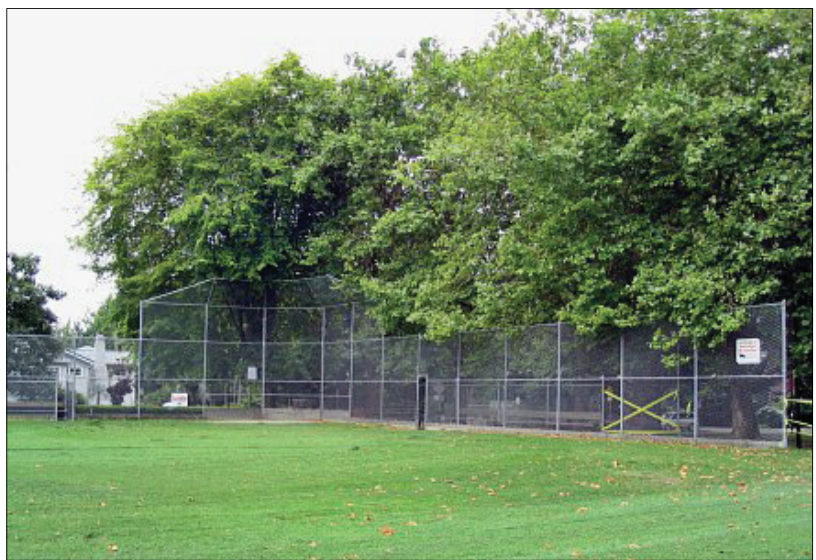


pose of parks developed. The findings of the study therefore show that there is a strong relationship between the settlement structure and the purpose and type of parks developed in a city. The changes in the demographic characteristics therefore have implications on the design and use of parks.

\section{Actors in Park Development (1945-1965)}

The vital role played by individual city residents, the private sector, community associations, parks board and the provincial government in the development of parks in the Pre-World War II era did not change much during the Post-World War II era. However, their role shifted from financing park development to a more participatory role due to the massive acquisition of parks and park land by the City of Vancouver Parks Board. Therefore, this made the City of Vancouver Parks Board the main actor in the development and management of parks but they were still supported by the community and the Provincial Government.

Community residents for example voted to pay more taxes to fund the construction of Kerrisdale Community Centre at Kerrisdale Centennial Park in 1952 (Vancouver Parks Board, 2014). Community and individual contributions to the development of parks shifted from mostly donations to focus more on taxes. However, donations by some community residents continued to be an integral part of park development. In 1945, Jonathan Rogers donated $\$ 100,000$ for the development of Jonathan Rogers Park in the vicinity of Broadway and Cambie Street (Vancouver Parks Board, 2014).

Community associations also played an integral role in the development of parks. In 1955, the South Slope Community Association gave financial support for the construction of the Community Hall on Moberly Park. The Sunset Community Association on the other hand also undertook a fundraising campaign to build a community recreation facility in 1945 (Vancouver Parks Board, 2014). The role of community associations was mostly in the form of fund-raising to support the development of parks. Public corporations such as the Central Housing and Mortgage Corporation also contributed to park development by selling their land to the Parks Board. The land for the development of Fraserview Park for instance, was purchased by the Parks Board from the Central Housing and Mortgage Corporation in 1952 (Vancouver Parks Board, 2014).

\section{Characteristics of Parks (1945-1965)}

The Post-World War II period saw an increase in the number of physical structures and area of concrete landscaping on most parks. This was as a result of the creation of recreational facilities in most newly developed parks and the upgrading of existing parks with recreational facilities. Parks developed during this period had both green landscapes and concrete landscapes due to the construction of facilities such as community centers, playgrounds, tennis courts, swimming pools, and basketball courts among other recreational facilities.
The recreational facilities for Memorial Smith Park which was officially opened in 1926 was created after World War II. The recreational facilities that were developed on the park include playgrounds, tennis courts, cricket pitches, field hockey, ball hockey and running tracks after the Second World War (Vancouver Parks Board, 2014). The community center and outdoor pool was also constructed in 1956 (Vancouver Parks Board, 2014).

The results of the study show a relationship between the purpose of establishing parks and the characteristics of the parks. Parks created for recreational purposes will have more physical structures and acreage of concrete surfaces than parks developed for ecological purposes. Some of the existing parks were upgraded to include museums and other memorial installations. The Maritime Museum on Hadden Park according to the Vancouver Parks Board (2014) was opened on June 11, 1959. The parks developed during this period effectively combined green landscaping and recreational facilities. Fraserview Park which was developed in 1952 was designed with playground facilities and its landscaping (Vancouver Parks Board, 2014).

\section{Park Management and Funding (1945-1965)}

The City of Vancouver Parks Board has been responsible for the management of parks in the city since the creation of Stanley Park in 1888. The management of parks during the Post-World War II period became more complex and financially demanding due to the physical and demographic expansion of the city. Park development was financed through multiple sources of funds such as taxes, donations, and community association fundraising activities. In 1956, the City of Vancouver Parks Board also developed initiatives such as the Local Improvement Bylaw and the neighbourhood fundraising and capital for the development of parks. The Local Improvement Bylaw helped in the construction of a $\$ 100,000$ recreational facility at Douglas Park in 1964 (Vancouver Parks Board, 2014).

The level of donations of land for park development by individuals and the private sector was reduced during the Post-World War II era. This was as a result of the physical and demographic expansion of the City of Vancouver thus reducing the availability of land and increasing the economic value of land. This implies that the ability for individuals and the private sector to donate land for park development relies on the availability and economic value of land. The growth of the city increased the pressure on land resource, thus limiting the availability of land for park development.

\section{Summary of Findings and Theoretical Implications (1945-1965)}

The recreational nature of parks developed during this period helped to promote social activities and interaction in the City of Vancouver. The parks developed provided more space for picnics, swimming and other social activities. Community centers were also developed to serve as meeting places and indoor recreational activities especially during the winter seasons. The major challenge that faced the development 
and management of parks in the City of Vancouver during this period was the growing pressure on land due to the demographic and economic expansion of the city. The conversion of arable land into industrial and residential areas adversely affected the availability of land for park development and also increased the cost of creating new parks due to the increase in the economic value of land.

Overall, the number of the parks developed from 1945 to 1965 was about $31 \%$ of the total number of parks in the City of Vancouver. The percentage of park area developed was also about $13 \%$ of the total park area in the city. This clearly indicated that the rate of increase in the total number of parks was higher than the rate of increase in the total park area. The creation of smaller neighborhood parks led to more parks being created during this period. However, the total area of parks developed was less than the total area of parks developed during the PreWorld War II era. This was due to the fact that large parks such as Stanley Park and Queen Elizabeth Park were developed before World War II. This implies that, functionally, there is a major difference in increasing the total number of parks in a city and increasing the total park area.

Generally, an increase in the number of parks promotes the accessibility of parks to city residents. On the other hand, increasing the park area helps to increase the total area of green spaces thus promoting sustainable city development. The contribution of parks to sustainability cannot be measured based on the increase in the total number of parks. Goodland \& Daly (1996) describes environmental sustainability as a process that allows human society to live within the limitations of the biological and physical environment. There is the need to include important factors such as the total area of green landscaping and the connectivity between the parks, which allows interaction between the natural habitats.

Additionally, there was an upgrade of existing parks with recreational facilities. Also, most of the newly developed parks were designed with various recreational facilities. This contributed to an increase in the number of physical structures and concrete surfaces on the parks compared to the presence of available concrete landscapes on the Pre-World War II parks. In as much as some of the parks developed during the Pre-World War II era had recreational facilities, the emphasis of parks developed from 1945 to 1965 was more on social goals. This helped in promoting social functions such as creating spaces for recreational activities while limiting ecological functions such as preserving nature in cities to depict some character of the country.

\section{Park Development After 1965}

The physical expansion of the City of Vancouver through demographic and economic growth has affected the development of parks from 1965 until now. The city has seen tremendous infrastructural and educational transformation during this period. Major educational facilities such as the Simon Fraser University were constructed within this period. The physi- cal, infrastructural, demographic and economic growth of the city led to an increase in the demand of land and subsequent increase in the pressure on existing park lands from other competing land uses.

\section{Purposed of Park Development (1965+)}

The City of Vancouver continued to upgrade existing parks and created new parks to meet the growing and diverse needs of the population. The parks that have been created from 1965 until now are mostly neighborhood parks that helped in promoting social interactions and activities among residents in the various neighborhoods. These parks mostly have play grounds, recreational facilities, walking, cycling and horse riding trails. The continuous increase in the development of playgrounds and recreational facilities in the various parks in the City of Vancouver is not only because of population growth but also because of the increase in apartment buildings in the city.

Apartment buildings do not have backyards to provide space for recreational and other social activities. This implies that whenever there is an increase in apartment buildings in a city, the demand for park space in neighborhoods also goes up which is the case of the City of Vancouver. The development of parks is therefore not only influenced by changes in demographic characteristics, but also changes in dwelling types and housing design.

The parks were also created to meet the needs of the ethnically diverse population of the City of Vancouver. According to Statistics Canada (2008), the percentage of immigrants to the total population in the City of Vancouver increased from $44.4 \%$ in 1996 to $45.1 \%$ in 2006. The high percentage of immigrants in the city has contributed to its diverse demographic characteristics. The Sun Yat-Sen Classical Chinese Garden in Figure 5 opened in 1997. This garden is a representation of Ming Dynasty-era making it the first of its kind outside China (Vancouver Parks Board, 2014).

Parks are currently being developed to promote recreational activities, educational programs and cultural programs. Parks are also developed as a means of brownfield remediation. The increase in contaminated land due to urban and industrial growth necessitated the use of parks as brown field remediation tools. Everett Crowley Park, which used to be Kerr Road Dump was closed as a landfill site for 25 years before being redeveloped into a park in 1987 (Vancouver Parks Board, 2014). Parks were also developed for neighbourhoods that are park deficient, as determined by the Parks Board and City Council. Ebisu Park, for instance, was created at a cost of $\$ 3,363,000$ to meet the park needs of the Marpole neighborhoods (Vancouver Parks Board, 2014).

\section{Actors in Park Development (1965+)}

The City of Vancouver Parks Board during this period had embarked on the acquisition of all the parks in the city. This made the Parks Board the main actor in the development and 
management of parks in the city. The mandate of the City of Vancouver Parks Board is to nurture, maintain and develop Vancouver's urban parks and recreational facilities (Vancouver Parks Board, 2014). The city residents played an important role and continue to contribute towards the creation and management of parks in Vancouver. They participate actively in the elections of competent park authorities to manage existing parks and create new ones.

Community consultation is currently an important aspect of the park development process. Community residents participate in the decision making process regarding the management and use of parks. Nelson Park, which was redeveloped in 2007, went through a three-year community consultation period (Vancouver Parks Board, 2014). Despite the importance of community consultation in ensuring the sustainability of parks developed, it sometimes led to delays in the implementation of the formulated park policies.

The pressure on parklands as a result of the economic and demographic expansion of the city contributed to the formation of park advocacy groups such as the Vancouver Save Our Parkland Association and the VanDusen Botanical Garden Association. These advocacy groups helped in the protection of parklands from competing land uses. There is currently a partnership between developers and the City of Vancouver to create parks in the city. Marathon Development Inc. for instance supported the construction of Coal Harbour Park at a cost of $\$ 1.5$ million as part of their Community Amenity Contribution (Vancouver Parks Board, 2014). The City of Vancouver currently classifies the development of parks as an amenity, thus making it the role of developers to provide parks for neighborhoods.

Garvin \& Berens (1997) support this approach of developing parks in the City of Vancouver by arguing that the least expensive way to provide public spaces in developed areas is to have property owners create, manage, and maintain the park. The problem with this approach however, is that because developers want to maximize profit, the park sizes are mostly limited in order to help them maximize the use of space.

The partnership between developers and the City of Vancouver in the creation of parks also explains the reason why more parks were developed during the Post-World War II. However, parks were smaller in sizes thus reducing the total park area. Generally, developers want to ensure the efficient use of land in order to maximize profit. The Yaletown Park was created through a partnership between the City of Vancouver and developer Bruno Wall of Yaletown Park Condominiums (Vancouver Parks Board, 2014). The role of landscape architects in the design of parks in the city is also very vital. Durante and Kreuk Limited are examples of landscape architects actively involved in the design of the city's current neighborhood parks.

\section{Characteristics of Parks (1965+)}

The parks that were developed in the City of Vancouver dur-

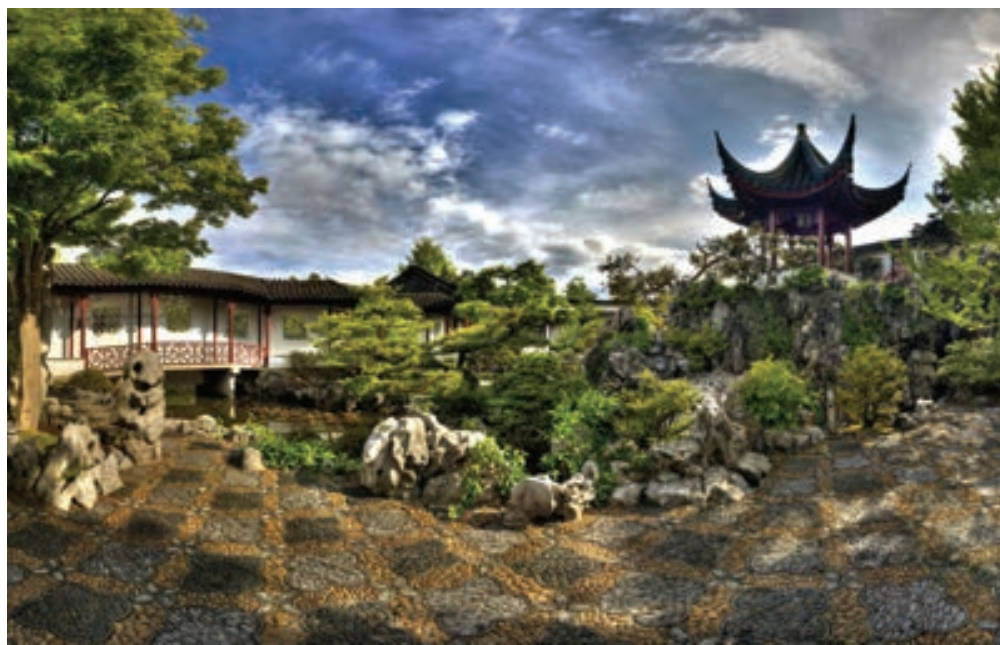

Figure 5: Sun Yat-Sen Classical Chinese Garden. (source: Vancouver Parks Board, 2014)

ing this era combined green spaces with recreational facilities to promote social activities. These parks effectively combined active and passive recreational opportunities. This therefore made their characteristics similar to the characteristics of parks created from 1945 to 1965 . The city authorities continued to modernize the parks with the inclusion of monuments, recreational facilities, and providing and maintaining existing trails.

Between the years 2002 and 2004, the Victory Square site, for example was much improved with hard landscaping (Vancouver Parks Board, 2014). In as much as more parks were created during this period, there are still questions about the ability of these parks to contribute to the sustainability targets of the City of Vancouver. This is because the increase in number of parks did not correspond to the increase in total acreage of green spaces created, which is critical towards the achievement of sustainability goals.

Harnik (2000) argued that not every acre classified as parkland is an area with grass and trees but most of these parks have buildings such as museums, planetariums, and aquariums. The increase in the number of physical structures and concrete landscaping on parks adversely affects the ecological functions of the parks. Generally, the development of more concrete landscaping and physical structures on parks reduces the total area of green spaces on these parks thus adversely affecting the environmental functions of the parks. Parks developed in the City of Vancouver from 1965 until now have more physical structures and recreational facilities to help promote social activities and interactions. In 2011, for instance, Grand View Park was upgraded with a playground, pathways, sport court, and field house (Vancouver Parks Board, 2014).

Parks developed featured both green and concrete landscaping consisting of fountains, benches, dog parks, playgrounds, open lawn space, trees and shrubs. The Vancouver Winter 
Olympics organized in 2010 also influenced the development of parks. The Hillcrest recreation and community complex currently under construction on Hillcrest Park included the Vancouver Paralympic Centre (Vancouver Parks Board, 2014).

\section{Park Management and Funding (1965+)}

The City of Vancouver Parks Board currently manages the parks in consultation with the city residents and other key stakeholders. The management and development of parks in the City of Vancouver is currently funded through a variety of sources including taxes, user fees, donations and community association fund raising activities. This is supported by Harnik (2000) who indicated that, sources of funds for the development of parks include taxes, fees, grants and donations, state and federal support and capital expenditure.

The Harbour Green Park, which was opened in 2002, was funded through the Marathon Development Corporation's recreational contribution showing the important role private developers play in park funding (Vancouver Parks Board, 2014). In 1990, the City of Vancouver approved a park impact fee program to provide funding for the acquisition and development of urban parkland (Vancouver-Clark Comprehensive Parks, Recreation and Open Space Plan, 2007). The Vancouver-Clark Comprehensive Parks, Recreation and Open Space Plan (2007) describes the Park Impact Fee Program as the establishment of the level of service standards for urban parks and assesses the park impact fees on new residential development to offset the cost of providing these parks.

Civil society and charitable organizations such as the Devonian Foundation also play a vital role in park development through financial support. The Devonian Foundation contributed over $\$ 600,000$ to help protect the parkland of Devonian Harbour Park (Vancouver Parks Board, 2014). The support of private individuals through donation also helped in the development of some parks in the City of Vancouver. Jean Beaty, for example, sold her home to the Parks Board below the market value for the development of the Jean Beaty Park in 1990 (Vancouver Parks Board, 2014).

The partnership funding model was also used in funding the development of parks in the City of Vancouver. This model brings financial resources from city authorities, provincial government, private individuals, community organizations and private organizations together to fund the development of parks. The VanDusen Garden which was created in 1975 represents the effective application of the partnership funding model. The park was developed through a collaboration between city authorities, provincial government and private individuals (Vancouver Parks Board, 2014). The development of the park was funded through a $\$ 1$ million contribution by the City of Vancouver, \$1 million contribution by the provincial government and $\$ 1$ million contribution by W.J VanDusen (Vancouver Parks Board, 2014).

\section{$\underline{\text { Historical Trends and Patterns (1965+) }}$}

The development of parks during this period promoted economic development, environmental conservation, and social interaction and activities. Park ands in the City of Vancouver contributed to economic growth through increases in both internal and external tourism generated through the use of parks, such as Stanley Park and Queen Elizabeth Park. The green landscaping on the parks served both environmental and aesthetic purposes. The increase in recreational facilities on the other hand helped in promoting physical activities, social activities, and interaction among city residents

The City of Vancouver developed a higher number of parks during the period under review than any other period. These parks, which are mostly neighborhood parks with recreational facilities constitute $51.36 \%$ of the total number of parks in the city. In terms of the total area of park created, this period experienced the development of a lower park area compared to the Pre-World War II era as shown in Table 3. The acreage of parks created during this period was $22.72 \%$ of the total park area. The calculation of the total park area did not separate green landscape from concrete landscape. Table 3 below shows the historical trends in the area and number of parks created.

The historical trends clearly show a major difference between the number and size of parks. The creation of more parks, according to the study, does not necessarily mean an increase in the total area of parks created. Most cities normally measure their achievements in the creation of parks based on the total number of parks created but this measure is only applicable if the city is measuring its performance in ensuring accessibility of parks to city residents. The City of Vancouver has been able to increase the accessibility of parks to its residents as a result of the continuous increase in the total number of parks in the city.

However, cities using the development of parks as the means of achieving their sustainability goals as in the case of the City of Vancouver, must go beyond using only the total number of parks created. They should also include the total area of parkland developed and the area of green landscaping provided. The study showed that the increase in total number of parks does not automatically lead to the increase in the total area of park land, as shown in Figure 6.

Table 3: Percentage Park Area and Percentage Number of Parks. (Source: Vancouver Park Board, 2014)

\begin{tabular}{|l|l|l|l|l}
\hline \multirow{2}{*}{ Period } & \multicolumn{2}{|c|}{ Park Area } & \multicolumn{2}{c}{ Number of Parks } \\
\cline { 2 - 5 } & Area (Acres) & $\%$ & Number & $\%$ \\
\hline Pre-World War II Era & 2,528 & 64.75 & 68 & 30.91 \\
\hline 1945 to 1965 & 489 & 12.53 & 39 & 17.73 \\
\hline $1965+$ & 887 & 22.72 & 113 & 51.36 \\
\hline Total & 3,904 & 100 & 220 & 100 \\
\hline
\end{tabular}


The contribution of parks towards the achievement of sustainability goals can be measured by calculating the difference between the total area of concrete landscaping and the total area of green landscape before assessing the trends. This data needed for this approach can be collected using Geographic Information Systems and current Geo-rectified aerial photography. Parks have economic, social and environmental values and these values can only be ascertained if the available data on park use and benefits are improved. Figure 6 gives a pictorial representation on trends and patterns of the park area and number of parks. Generally, the City of Vancouver Parks Board and Developers continue to perform their role in creating neighborhood parks with adequate recreational facilities. City authorities should however, be concerned about the effects of increasing these recreational facilities and physical structures on the parks in the attainment of Vancouver's 2020 vision of being the world's greenest city.

In order to achieve the target of being the World's Greenest city by 2020, the City of Vancouver has formulated 10 main goals. These goals include the promotion of green economy, climate leadership, green buildings, green transportation, zero waste, access to nature, lighter footprint, clean water and local food production. It must, however, be noted that the focus of this paper is on improving access to nature through the development of efficient and effective park systems.

\section{Historical Patterns and Trends-Population Park Ratio}

The analysis of the trends in green space per capita helps in the assessment of the level of pressure on urban greeneries. Iniewska (2008) describes green space per capita as a useful indicator of green space availability as it measures the level of accessibility by each city resident. The City of Vancouver Parks Board's standard of maintaining the provision of parkland in the city is 2.75 acres per thousand people (Iniewka, 2008). The historical trends and patterns clearly show that the City of Vancouver's parkland per capita is higher than their official standards. At the same time, there are serious concerns in the ability of the city to maintain the current standard as the parkland per 1,000 population has been reducing since 1891 .

The parkland per 1,000 population has reduced from 84.0 acres in 1891 to 6.5 acres in 2011. This shows that the available parkland to city residents has been reducing since 1891 due to population growth which has serious implications on the ability of the City of Vancouver to maintain its standards of 2.75 acres per thousand people and achieve its objectives of being among the world's greenest cities. Table 4 shows the trends and patterns of park availability to city resident from 1891 to 2011.

\section{Population Density}

Harnik (2000) argues that urban parks must be considered in the context of a city's population density. The World Bank (2014) defines population density as the number of people per

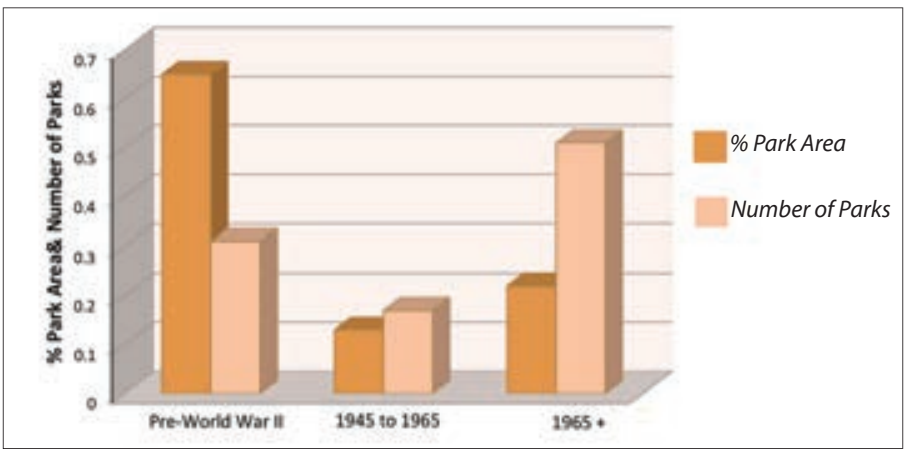

Figure 6: Number of parks and park area.

square kilometer of land area. The population density helps in assessing the pressure on land resources in relation to population growth. The City of Vancouver was amalgamated in 1929. The population density was therefore calculated based on the first population census after the amalgamation.

The study revealed that the higher the population, the higher the number of persons per square acre of land. The increase in the number of persons per square acre of land contributed to the increase in the pressure on land resources in the City of Vancouver. The study showed that the higher the number of persons per square acre, the lower the available park land per 1,000 population. This indicates that the increase in the pressure of land resources due to population growth has adversely affected the availability of land for park development.

The number of people per square acre increased from 10.09 persons in 1941 to 22.11 persons acres in 2011 while the available park land per 1000 population also decreased from 9.2 acres per 1000 population in 1941 to 6.5 acres per 1000 population in 2011 as indicated earlier. This shows that population growth in the City of Vancouver has adversely affected the availability of land and park accessibility to city residents. There is therefore an overall relationship between population growth, availability of land and availability of parkland. The ability of cities to develop and maintain more parks highly depends on the availability and cost of land. Table 4 shows the historical trends and patterns in the population density in the City of Vancouver from 1891 to 2011.

Table 4: Population / Park Ratio (1891 to 2011).

\begin{tabular}{|c|c|c|c|}
\hline Year & Population & $\begin{array}{c}\text { Total Park Area } \\
\text { (Acres) }\end{array}$ & $\begin{array}{c}\text { Park Acreage Per } \\
\mathbf{1 , 0 0 0} \text { Population }\end{array}$ \\
\hline $\mathbf{1 8 9 1}$ & 13,709 & 1,151 & 84.0 \\
\hline $\mathbf{1 9 4 1}$ & 275,353 & 2,540 & 9.2 \\
\hline $\mathbf{1 9 6 6}$ & 410,375 & 3,030 & 7.3 \\
\hline $\mathbf{2 0 1 1}$ & 603,502 & 3,904 & 6.5 \\
\hline
\end{tabular}




\section{Conclusion}

The demographic and physical expansion of cities has implications on the availability, management, and the use of parks. Garvin \& Berens (1997) recommend that each generation through its public and private sectors must keep investing and reinvesting in its urban parks in order to ensure that the next generation has an environment worth preserving. The history of urban parks helps academics, professional planners, and policymakers to understand the nature, characteristics and the purpose of creating parks. Historical analysis mostly relies on already existing information either in the form of oral communication or documentary data.

The development of parks in the City of Vancouver since the 19th century has been approached from a multi-stakeholder perspective. The historical trends of the park development revealed that there has been an increase in the number of physical structures on the various parks. The increase in recreational facilities on the parks has also contributed to the increase in the area of hard landscaping thus restricting the ecological functions of the parks. The size and number of parks developed depends on the availability and cost of land.

The total park area developed during the Pre-World War II period was more than the total park area developed during the Post-World War II period. There was however an increase in the number of parks from the Pre-World War II to the Post-World War II era. The larger the area of parkland, the more efficient its ecological function, while an increase in the number of parks increases park accessibility. The historical trends of the development of parks in the City of Vancouver have implications for park value, funding, maintenance, and management.

\section{References}

Byrne, J. \& Sipe, N. 2010. Green and Open Space Planning for Urban Consolidation - A Review of the Literature and Best Practice. Urban Research Program; Issues Paper 11, Brisbane, Griffith University.

City of Vancouver Archives. 1997. Administrative History of Vancouver Parks Board. VPK-S76. City of Vancouver

City of Vancouver \& Clark County. 2007. Vancouver-Clark Comprehensive Parks, Recreation, and Open Space Plan 2007. Vancouver.

Cranz, G. 1982. Politics of Park Design. Cambridge, MA: The MIT Press.

Garvin, A. \& Berens, G. 1997. Urban parks and open space. Washington D.C.: Urban Land Institute and Trust for Public Land.

Goodland, R \& Daly H. 1996. Environmental Sustainabilty: Universal and Non-Negotiable. Ecological Applications, Vol. 6,
No. 4, pp. 1002-1017

Hakim, C. 1982. Secondary Analysis in Social Research: A Guide to Data Sources and Methods with Examples. Boston: Allen \& Unwin.

Harnik, P. 2000. Inside City Parks. Washington D.C.: Urban Land Institute and the Trust for Public Land.

Hinds, D. B. 1979. The Evolution of Urban Public Park Design in Europe and America: Vancouver Adaption to 1913. University of British Columbia, Vancouver, B.C

Iniewska, M. 2008. Think City, Dream Vancouver: Policy Brief, Keeping Vancouver Green, Protecting and Diversifying Urban Green Spaces. Vancouver.

McHarg, I. 1971. Design with Nature, Garden City: Doubleday.

Roy, P. E. 2014. Nathan Coschi \& Leanna Fong. Canadian Encyclopaedia Online. Retrieved 15th August 2014.

Sandalack B.A \& Uribe, F. G. A. 2010. Open Space Typology as a Framework for Design of the Public Realm. Calgary: University of Calgary Press

Sherer, P. M. 2003. The Benefits of Parks: Why America Needs More City Parks and Open Space. San Francisco: The Trust for Public Land.

Toledo, F.D. \& Douglas, G.D. 2012. Construction Free Space-A Study on Urban Parks. Revista da Sociedade Brasileira de Arborização Urbana Vol. 7, No. 2, pp. 9-22 (Brazil).

Vancouver Parks Board. 2014. Parks, Recreation and Culture. In $<$ http://vancouver.ca/parks-recreation-culture.aspx >.Retrieved March 6, 2014.

Williams, S. M. 2002. Sustaining Urban Green Spaces: Can Public Parks Be Protected Under the Public Trust Doctrine? S. C. Environmental Law Journal, Vol. 10.

World Bank. 2014. Population Density. In <http://data.worldbank.org/indicator/EN.POP.DNST>. Retrieved September 7, 2014.

Yin, R. K. 2008. Case Study Research Design and Methods. 4th edition. Thousand Oaks: Sage. 